\title{
Rural Tourism as a System Innovation: Social Transformation in a Protected Area
}

\author{
A.F. Rachman \\ Tour and Travel Department \\ Trisakti School of Tourism \\ Jakarta Indonesia \\ E-mail: arief@stptrisakti.ac.id
}

\author{
C. Suryono \\ Graduate Program \\ Trisakti School of Tourism \\ Jakarta, Indonesia
}

\begin{abstract}
Rural area in Wonorejo is an agriculture and fisherman based village. The village bordered by Baluran National Park. Conflicting between locals and the national park happened because of exploration of natural resources by locals. Tourism concept taken as a solution for the conflict. This is a social process that contested by stakeholders, such as local community, visitors, national park and local government. This entire stakeholder has their own self-interest, as the elements of their stated social concept. Different values of elements between stakeholders created interest between them. The research used explorative and descriptive methodology to find out actor network theory on the physical and social transformation between stakeholders. The results of this research are tourism is an innovation of social system at local community of Wonorejo, Village, then they transform their selves from exploration of natural resources of Baluran National Park into a preserver of national park.
\end{abstract}

Keywords-rural tourist destination, protected areas, system innovation, actor-network theory, social tranformation Introduction

\section{INTRODUCTION}

In the beginning 1980 's, there were some illegal logging and others activities that exploited natural resources. This became a conflict between local villagers and national park. Baluran National Park claimed the area of forest is protected by law, but at the other side, locals villagers claimed of the forest is belonged to their ancestor. There should be a solution regarding this situation.

The concept of tourism was a solution. It was introduced fot the first time to villagers in the year 2004. The idea initiated by Baluran National Park. It was an idea of took overnight visitor to the park to stay over at villager's homestay. The idea worked successfully, the were good interaction between locals and national park. There were social transformations in the context of actor networking theory. System innovation was also introduced by stakeholders at the area.

System innovation was describeb in the study of bailout finance when payment system of pilgrimage tour of umroh was introduced by Mandiri Syariah Bank and PT. Ganes Wisata. The umroh participants were able to join the pilgirmage tour before they settle full payment to the Bank and off course, they became clients of the bank (Firdyanto and Rachman, 2012).
Tsunami nature disaster of Pangandaran Beach impacted to importance of early warning system technology at tourist destination and also learning organisation at the area such as way of evacuation and its process. Science and technology dominated the system innovation in reconstruction after disaster (Rachman, 2014).

Role of local people in developing Gili Trawangan as an island destination is an interesting innovation. Bottom up approaching from local people increase number of foreign tourist. Level of acceptance of locals (although most of them are moslem) to western culture is the key of system innovation at the island (Rachman, 2015).

Local participation is also as a success story when people of Sawarna develop a village into community-based tourism, thus role of informal leader at the destination (Rachman, 2014).

Research question of this study is how tourism concept as a system innovation shaped a social transformation of Wonorejo Village

The objectives of study to determine the social transformation that occurs when the tourism introduced into an activity in Wonorejo Village. Tourism destinations is an area is interconnected spatial, temporal and sociocultural, so it has a certain image, in which there are components of tourism and community elements interact.

\section{LITERATURE REVIEW}

\section{A. Rural Tourist destination}

Rural tourist destination attraction in Indonesia mostly showed beauty of ricefield as a daily activitiy. The use of resources also depends to typical geography resources, wether beach or mountain resources (Rachman, 2014).

In a destination area, there are several components that must be held in the planning and development of tourism, consisting of a tourist attraction, accommodation facilities, restaurants, souvenir shops, tourist information centers, shops, roads, transport services. In tourism, these components are practically necessary elements of tourist destination (Spillane, 1991) is a tourist attraction, facilities, infrastructure, transportation, hospitality and security. In addition to physical artifacts that are required in the development of tourism destinations, there are components of the non-physical which 
also determines the development of tourism destinations in the region.

The attraction of Wonorejo Village present a daily life of the village where mostly are Javanesse people. Upon arrival at the village, tourist will be welcomed by a local people that dedicated himself as a local operators of homestay. He took visitors to the village attraction, mostly rural-based attraction, such as a Perengan Pandean Beach, rice field, dairy milk production, nata de coco home industry and fishery industry. Some traditional event are also held in the ceratin time.

The facilities of Wonorejo Village is a traditional one when they make toilet and bathing shower in their own house, use a local house as tourist's accommodation and place to eat. Souvernir shops are provided by the locals.

The infrastructure is a simple one. There is an electricity network, locals use TV cable, radio and cellphone networl is good. There is a good asphalt road for accessibility. Water irrigation established well, and good enough water supply for drink. Tourist information is availbale by local people where they make a small business unit.

There is land and seawater transportation on the site. It is easy to get to the entrance gate of destination because located enroute of national road. There is also a parking lot provided by local villagers.

As it is a village, it has good level hospitality and security. Warm greeting and locally type of service will welcome all the visitors to the village. Even the visitors are allowed to see their part of local house, such as kitchen, bedroom and family room. There is good interaction between host and guest at destination.

\section{B. Protected Area}

IUCN (Eagles and Mc Cool, 2002) divided categories of national parks protected areas as follows:

1. Category I

Strict Nature Reserve/Wilderness Area: Protected area managed mainly for science or wilderness protection.

2. Category I A

Strict Nature Reserve: Protected area managed mainly for science

\section{Category I B}

Wilderness Area: Protected area managed mainly for wilderness protection.

4. Category II

National Park: Protected area managed mainly for ecosystem protection and recreation.

\section{Category III}

Natural Monument: Protected area managed mainly fro conservation of specific natural features.

\section{Category IV}

Habitat/Species Management Area: Protected area managed mainly for conservation through management intervention

\section{Category V}

Protected Landscape/Seascape: Protected area managed mainly for landscape/seascape conservation and recreation.

\section{Category VI}

Managed Resources Protected Area: Protected area managed mainly for sustainable use of natural ecosystems.

Sustainable utilization concepts related to national parks and tourism should imply a new way of doing business, in a new form. It is important to understand there are four elements in sustainable ecosystem management, namely (Woodley, 1992):

\section{Clear Objectives}

The purpose is obviously a very important thing in tourism, particularly with regard to the ecosystem. An example is whether the purpose of national parks safeguard the population and habitat of biodiversity of flora and fauna? Thus the tourism activity in a national park should not disturb the population and habitat.

\section{Knowledge}

When tourists visit the national park, they should be informed knowledge of the national parks in the form of predeparture information and information during the visit. It contains information about the function of the national park as a conservation area so as not to do anything that damages the flora, fauna and disturb the soil physical change (what to do and what don'ts). This is reinforced by the philosophy of "Take only photographs, leave only footprints".

\section{Advocacy of Travel}

Required a force of authority in setting activities, especially those related to tourism. Insistence tourist activity should be controlled by the authority managing the national park. The integration of the parties involved in the national park should be strengthened, so that continuity is maintained.

\section{Feedback or indicators}

Sustainable tourism should be seen in terms of sustainable ecosystem. Therefore the indicators used to measure ecosystem approach that serves as a guide in setting sustainability goals.

\section{Actor Network Theory}

Crawford (2004) describe that Actor network theory (ANT), also known as enrolment theory or the sociology of translation, emerged during the mid-1980s, primarily with the work of Bruno Latour, Michel Callon, and John Law. ANT is a conceptual frame for exploring collective sociotechnical processes, whose spokespersons have paid particular attention to science and technologic activity. Stemming from a Science and Technologies Studies (STS) interest in the elevated status of scientific knowledge and counter to heroic accounts or innovation models, ANT suggests that the work of science is 
not fundamentally different from other social activities. ANT privileges neither natural (realism) nor cultural (social constructivism) accounts of scientific production, asserting instead that science is a process of heterogeneous engineering in which the social, technical, conceptual, and textual are puzzled together (or juxtaposed) and transformed (or translated).

Crawford (2004) also stated that as one of many antiessentialist movements, ANT does not differentiate between science (knowledge) and technology (artifact). Similarly, proponents do not subscribe to the division between society and nature, truth and falsehood, agency and structure, context and content, human and non- human, microlevel phenomenon and macrolevel phenomenon, or knowledge and power. Nature and society, subjectivity and structure, and fact and fiction are all effects of collective activity. ANT advances a relational materiality, the material extension of semiotics, which presupposes that all entities achieve significance in relation to others. Science, then, is a network of heterogeneous elements real- ized within a set of diverse practices.

Law (2007) assumed that nothing has reality or form outside the enactment of those relations. Its studies explore and characterise the webs and the practices that carry them. Like other material-semiotic approaches, the actor-network approach thus describes the enactment of materially and discursively heterogeneous relations that produce and reshuffle all kinds of actors including objects, subjects, human beings, machines, animals, 'nature', ideas, organisations, inequalities, scale and sizes, and geographical arrangements.

In the study of transformation in Wonorejo Village will collaborate between the actor network theory with the tourism sector which forms the concept of cultural tourism as a form of social construction in Wonorejo Village. In the theory of social construction, development artifacts seen as a process that can not be predicted, according to the circumstances at the time (contingent process). According to this view, these changes can not be analyzed by following a fixed path and unidirectional, but refers to a number of determinants are heterogeneous. The changes are explained by reference to a number of differences which could be an obstacle even can lead to conflicts between social groups technologist. Each group has conceptual framework and the interests of each (self-interest).

The social groups involved in the preparation of strategies to win the interests and goals, and forming technology in accordance with their respective plans (Yuliar, 2009).

In the following review will describe the factors forming the social construction of determination in the study area. Identification of social groups as actors or social groups that had a role in creating an artifact of social processes that occur in an area. The social group is necessary to understand how the process of technology development).

\section{System Innovation}

System innovation is a process where changing the system between relation of stakeholders both public and private enterprises to overcome the problem that come up in the future (de Bruijn, 2004).
The possibilities for managing system innovation will mention three major causes:

1. Substance: Lack of knowledge

There is a knowlegde problem. The fundamenal nature of the change implies a large number of uncertainities: what is the relation between existing problem and the existing institution, structures and norms? Which of these institutions, structures and norms require change, and how will the change impact on the new situtation? What are the financial and social costs of the change process?

In many cases, there is either no knowledge at all about it, or the knowledge is contestable: different parties take different views. This makes a system innovation a risky exercise.

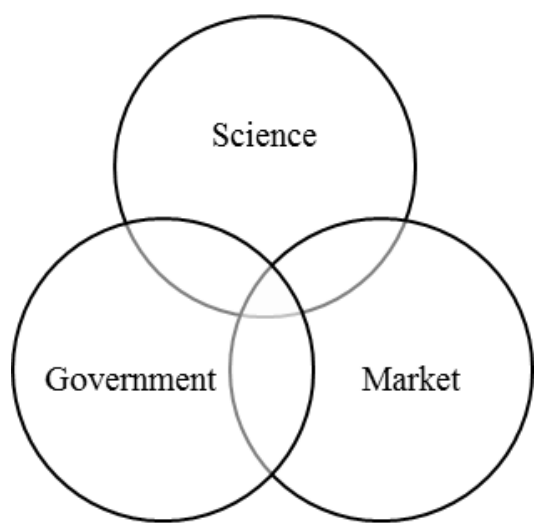

Fig. 1. Three sources of system innovation (de Bruijn, 2004)

2. Process: Consensus is not a matter of course

As a second case, system innovation affect the interest of many parties. In modern societies, such parties tend to operate in a network: They are interdependent, none in these parties has the power to impose its view on others. The parties involved tend to take different views about the desirability of system innovation. Some will support it, others will be neutral, others gain will seek to block the innovation. System innovation not only has a subtantives component. Its initiator should be able to play the management game: Who will I involve in the decision-making and how will I play the game so as to gain sufficient support for the innvovation.

3. Values: Conflicting public and private values. System innovation have a high potential for conflict between the public sector and private sector.

4. Knowledge-driven system innovation It is taken from the arena of science, research, knowledge and generated about the need for the possibilities of s system innovation. Scientifics arena also includes science practiced at universities and 
research institute as well as research companies and other institutions

5. Government-driven system innovation

The system innovation results from a political awareness that such an innovation is necessary and that there is sufficient support for and social acceptance of such innovation.

6. Market-driven system innovation

Possibilities for system innovation may also arise in the market; they tend to involve a coupling between new technological possibilites that are attractive from commercial point of view. The IT revolution in the nineteen nineties is an example of a marketdriven system innovation.

\section{METHODS}

The method used descriptive research method with explorative approach to describe and explore results of field observations. Descriptive method is a procedure of identification of problems investigated by describing circumstances (subject \& object) research during the study based on the facts as they appear (Bungin, 2007). This method is not limited to data collection, but also includes the analysis and interpretation of the meaning of these data, measure the dimensions of a symptom, held a symptom classification, set standards, establish relationships between symptoms were found and others. Peterson (1987) stated that qualitative research is used to adress a number of different types of objectives in the research process

\section{A. Data collection procedure}

Data collection in this study consisted of primary and secondary data. In this research emphasized using snowball interview technique, a method of sampling to see a network of relationships between people/organizations. This method is also to identify a case on a network that analogy based snowball that starts with a small portion then becomes large. As for the informants are:

1. Mr. David, homestay owner, 54 years old, live in Wonorejo

2. Chief of the Wonorejo village, 55 years old, live in Wonorejo

3. Basuki, visitors, 58 years old, live in Malang

\section{B. Data Analysis Methods}

It used descriptive method to facilitate researchers in determining the unit of analysis, the type of data used, methods of data collection, analysis and desired output in this study. Results of the interviews will be discussed and analyzed as a result of research. This research was conducted on August 2016, held at Wonorejo Village, Situbondo, East Java.

The analysis process begins with the identification of the social groups associated with social transformation in Wonorejo Village. After using the snowball method in the determination of social groups are involved, then discovered several groups of stakeholders in Wonorejo Village social groups identified as directly involved with the social transformation of the mine tour in Wonorejo Village. In Table 1 can be seen in the social groups involved in the formation of the social construction of cultural tourism in Wonorejo Village.

\section{TABLE I. SOCIAL GROUP IDENTIFICATION OF WONOREJO VILLAGE}

\begin{tabular}{l}
\hline Group identification of Wonorejo Village \\
\hline Homestay owner \\
Chief of Wonorejo village \\
Visitor to national park \\
\hline
\end{tabular}

\section{RESUlT AND DisCUSSION}

According to the data from the village, the surface soil of Wonorejo hills with those used for land productivity can be fertile. Area of land mostly used for housing, yards, ponds, and the rest is used for agriculture rice harvested twice a year. Most of locals depend their daily activities (agriculture and fisheries) to natural resources.
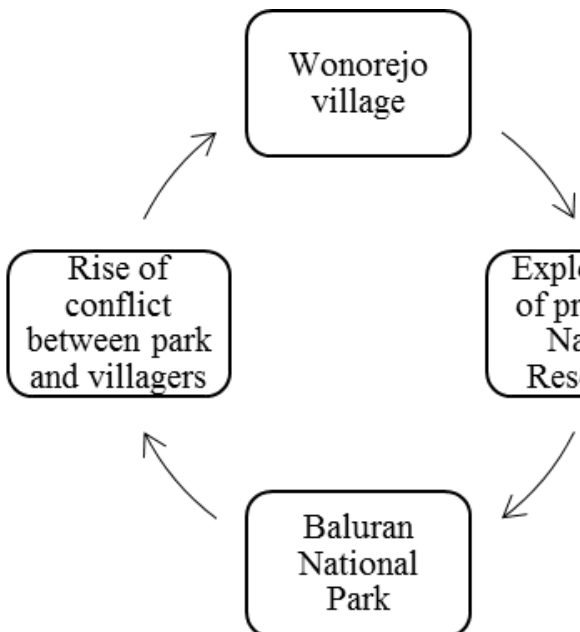

Fig. 2. Before tourism introduced to Wonorejo Village

Previously (1980s), the economic motives rised the exploitation of protected areas for some villagers. For example, the locals harvested tamarind inside the protected areas, collected woods and hunted local deers. There was not any other alternatives for economic activities and self-purposes that avoided the use of natural resources in Baluran Natural Park. Figure 1 when tourism not introduced yet to Wonorejo village.

In the beginning year 2004 tourism introduced to Wonorejo village. The figure 3 after tourism introduced came to Wonorejo Village that shape a new social construction at the destination. 


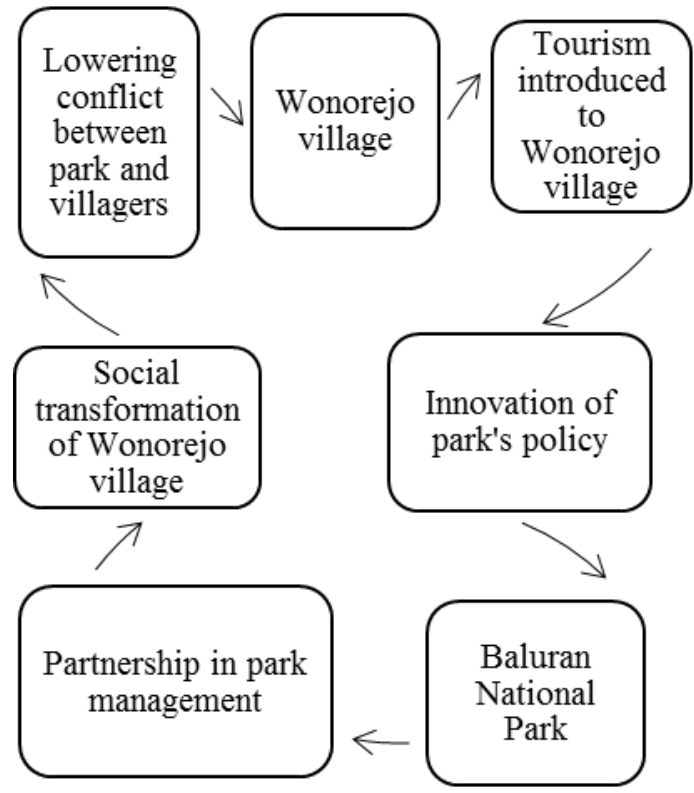

Fig. 3. After tourism introduced to Wonorejo Village, there is a social transformation

Baluran National Park to take action to prevent further destruction of forests and natural resources. The interesting thing about this precaution is, action to provide guidance to the local community in the village Wonorejo, and does not undertake coercive action.

As the time goes on, it as a precautionary measure to provide guidance to the perpetrators of encroachment without permission was a success. To improve the good partnership of between the two sides, then the Baluran National Park fostering economic approach by introducing tourism activities to the local community.

Further approach is believed by the Baluran National Park tourism as economic activities that can support conservation activities in the national park. Tourism as a smokeless industry is the right choice for the economic activity of the local community in the search for additional revenue.

Tourism Village Wonorejo two-year-old has tourism potential with beautiful beaches and farmland along the north coast of Java Island culture, especially the cultural mix of Java and Madura. In addition, household-based industrial agriculture and fishing are also coloring the attractiveness of this tourist village. Community participation and acceptance supported tourism activities in the village.

One introduction of tourism activities to the community is to give people an opportunity to manage the homestay for visitors who come to Baluran National Park and conducting overnight. There are also coaching the management of local foods, such as management of cow's milk which is used as candy, yoghurt, dodol and curd. There is a process of social change in the community, from the community that exploited the forests and resources into communities that preserve and conserve the forest.

\section{A. Physical Transformation}

This happen to support tourism activities such as establishing homestays at the village. There are thirteen homestays to accommodate visitors. Previously existing locally owned house only for their home, after that some physical changes occurred to provide tourist needs. Significantly, the physical changes can be seen at the entrance gate (written Desa Kebangsaan), entrance gate of Pereneng Beach, Museum of Kebangsaan and advertsing of homestay and small locals enterprises, such production of nata de coco and batik handmade.

Local did not renovated the whole part of the home, only sleeping and bath room. The physical changes of home also can be found just infront of the home. There is a signboard of advertising with phone number and contact person.

In the case of Bapak David homestay, family room set for the guest lobby where simple furniture chairs, table and guest book provided there. It also can be used for small talk between host and guest. The room also provided by TV cable and some refreshment of hot and cold water for the guest. Clean bathroom also designed for tourist, located at the backyard of the house.

There is no Tourist Information Center and Guides Association Wonorejo Village. This because all the information (what to see, to do and to buy) for tourist provided by homestay owner. This impacted to unscheduled tour program to in the village. But at the area of Pereneng beach where it is a boundary line between the village and park, provided a ticket box and ranger of the Baluran National Park.

\section{B. Transformation in Function}

Rural tourism of Wonorejo initiated by the Baluran National Park in the framework of the reduction of forest encroachment activities carried out by some people who still rely on natural resources conservation as their economic activity. The transformation is not an autopoetic process but this because of conflicting of interest between stakeholders. A concept of partnership in tourism activities for both (Baluran National Park and Wonorejo villagers) was done in a good pattern.

Elements of rural tourism destinations Wonorejo based largely on the activities of daily life of local people, such as agriculture, plantations and farms. The use of homes as lodging facilities (homestay) is clear evidence that the village empowered local resources compared with investments by private parties. This transfomartion impacted initiated by locals tourism authority and supported also by academician. Elements destinations as a whole is still in the exploratory stage (the stage of product life-cycle) that need proper management. 


\section{Pattern of Transformation}

The social transformation has a process that put into creating system innovation (De Bruijn, Van der Voort, Dicke, de Jong, Veeneman, 2004) . Table 2 shows a pattern of social transformation after system innovation where Baluran National Park is an initiator.

TABLE II. THE PATTERN OF SYSTEM INNOVATION

\begin{tabular}{ll}
\hline INISIATOR OF INOVATION & Baluran National Park \\
TYPE OF CHANGES & Staged \\
APPROACHING PATTERN & Top Down \\
KNOWLEDGE \\
PRODUCTION & Combination \\
PARTNERSHIP & $\begin{array}{l}\text { Public-Public } \\
\text { Partnership }\end{array}$ \\
\hline
\end{tabular}

Main issue was a conflict between Baluran National Park and local villagers of Wonorejo. It is a staged changes, initiated by the park to overcome the conflict, then local community's involvement to preserve the park, given alternative economic sources to locals. Phenomenon of Baluran National Park and Wonorejo Village is a sample of Top Down approach because it is initiated by the park authority. It started to preserve the park and benefited to local community of Wonorejo Village. Tourism is a keypoint that creating system innovation between the park and the village. This is a public-public partneship, where the park authority involved local community to preserve the park and shared issue of management.

There is a system innovation when social transformation contested between the park and local community of Wonorejo village. An intervention of policy to give solution to the problems of nature preservation, as it is showed in the Tabel 2.

\section{CONCLUSION}

Wonorejo Village has a unique tourist destination, which can be seen in terms of physical relics and culture can still be found until now and serve as an asset for the development of rural tourism. However, in addition to physical function, at Wonorejo Village also has a non-physical attractiveness. This can be seen from the social and cultural life of society is growing. Preservation of nature after transformation can be seen as a reputation of the village.

Baluran National Park played the role as an initiator of the transformation to the Wonorejo village, as it is as a top down approaching. At the other side, local community supported the initiation of transformation from the park. Based on the analysis of social transformations in Baluran National Park and Wonorejo Village as a tourist attraction, it can be concluded that formulate social transformation, both physical and functions in Wonorejo Village contested a system innovation.

\section{REFERENCES}

Bungin, B. 2007. Penelitian Kualitatif. Jakarta: Kencana

Burton, R. 1995. Travel Geography. London: Pittman Publishing

Crawford, C.S. 2004. Actor Network Theory in Ritzer Encyclopedia.

De Bruijn, H., Van der Voort, H., Dicke, W., de Jong, M., Veeneman, W. 2004. Creating System Inovation. Leiden: A.A. Balkema Publisher

Eagles, P.F.J., Mc.Cool, S.F. 2002. Tourism in National Park and Protected Areas (Planning and Management). Canada: CABI Publishing

Harman, G. 2009. Prince of Networks: Bruno Latour and Metaphysics. Melbourne: re.press

Firdyanto, I.N., Rachman, A.F. 2012. Inovasi Sistemik Pembiayaan Perjalanan Umroh Melalui Talangan Bank Syariah Mandiri (Studi Kasus PT. Ganes Wisata Indoesia. Call for Paper Business Ethics Global Ethic. Universitas Gajah Mada.

Latour, B. 2005. Reassembling the Social. Oxford: University Press

Law, J. 2007. Actor Network Theory and Material Semiotics, version of $25^{\text {th }} \quad$ April 2007 availableathttp://www.heterogeneties.net/publications/ Law2007ANTandMaterialSemiotics.pdf, (downloaded on $10^{\text {th }}$ January, 2015).

Peterson, I.K. 1987. Qualitative Research Methods for the Travel and Tourism Industry in Travel, Tourism and Hospitality Research (A Handbook for Managers and Researchers). Edited by J.R. Brent Ritchie and Charles R. Goeldner. Canada: John Wiley \& Sons, Inc.

Badan Pemberdayaan Masyarakat dan Perempuan Kabupaten Situbondo. 2015. Profil Desa dan Kelurahan Wonorejo. Kabupaten Situbondo.

Rachman, A.F. 2014. Geografi Pariwisata Jawa dan Bali. Jakarta: Media Bangsa

Rachman, A.F. 2014. A System Innovation of Pangandaran Nature-Based Tourist Destination, West Java Province (In a Perspective of Nature Disaster Risk Area). Call for Paper International Academic Conference on Tourism (INTACT). Tourism and Disaster: Managing Tourism in Disaster Risk Area. Universitas Gajah Mada.

Rachman, A.F. 2014. Model Parwisata Berbasiskan Masyarakat di Pantai Sawarna, Lebak, Banten. Penelitian Internal Puslitdimas STP Trisakti.

Rachman, AF. 2015. Pola Inovasi Sistemik Pemangku Kepentingan Di Destinasi Wisata Gili Trawangan, Propinsi Nusa Tenggara Barat. Jurnal Kepariwisataan Indonesia, Volume 10 No. 1 Desember 2015 Kemenpar.

Spillane, J.J. 1991. Ekonomi Pariwisata: Sejarah dan Prospeknya. Jogjakarta: Kanisius 
Yuliar, S. 2009. Tata Kelola Teknologi: Perspektif Teori Jaringan Aktor. Bandung: Penerbit ITB.

Woodley, S. 1992. Tourism and Sustainable Development in Parks and Protected Areas in Tourism and Sustainable
Development: Monitoring, Managing, Planning edited by Nelson, J.G., Butler, R., Wall, G. Canada: University of Geography University of Waterloo. 